Annals of Warsaw University of Life Sciences - SGGW

Land Reclamation No 40, 2008: 107-114

(Ann. Warsaw Univ. of Life Sci. - SGGW, Land Reclam. 40, 2008)

\title{
Evaluation of nonwoven geotextile as a filtration layer for internally unstable soils
}

DARIUSZ WOJTASIK

Department of Geotechnical Engineering, Warsaw University of Life Sciences - SGGW

\begin{abstract}
Evaluation of nonwoven geotextile as a filtration layer for internally unstable soil. This paper presents the laboratory tested results evaluating the performance of three nonwoven geotextile material used as filtration layer to protect for three internally unstable soils. Test research was performed in apparatus ASTM-D-5101 (1990) which was modified through installed additional piezometers in distance $4 \mathrm{~mm}$ and 8 $\mathrm{mm}$ above geotextile material tested. Applied piezometers ensure measurements pressure in layer of soil situated near fabric. Laboratory test were performed for total hydraulic gradient in range $i=1$ to 10 . Base on the test result the relationship for the evaluation of the change soil gradient ratio (soil layers 17 and $4 \mathrm{~mm}$ above the geotextile) is proposed.
\end{abstract}

Keywords: geotextile, gradient ratio GR, hydraulic gradient, soil gradient ratio SGR.

\section{INTRODUCTION}

Geotextiles are synthetic permeable textile material used with soil, rock or any other geotechnical engineering related material. Geotextiles are used in soils to perform many functions such as: reinforcement, separation, drainage and filtration. They are used as filters in many applications such as e.g.: road drainage systems, agriculture drainage and under geomembrances in retaining pounds (Rollin 1986). In the 90s, about 500 million $\mathrm{m}^{2}$ of geotextile was used annually only in North America in earth building (Huang and Gao 2008). The use of this material, instead of mineral filter, reduces earth work, increases stabilization and the speed of installation. In many cases, it also decreases the load on the structures.

A lot of studies and research have been carried out around the word in the last decades to evaluate the behavior of geotextile either in the laboratory (Giroud 1982, Heerten 1983) or in the field, and to define design criteria (Calhoun 1972, Lawson 1987). The selection criteria of geotextile for specific filter application must consider three conditions (Fisher et al. 1999):

1. Permeability-the geotextile must allow water to flow freely from soil situated near surface of the geotextile,

2. Retention-the geotextile must retain the majority protected of the soil particles, 3. Clogging-flow through the geotextile must not be restricted such that excessive pore pressures can develop.

One of the tests used to determine the soil-geotextile system permeability and clogging behavior is the gradient ratio test ASTM D-5101 (1990). The method uses the critical point GR $=1$ which indicates that geotextile during test has no effect on the hydraulic flow through the soil-geotextile system and the soil is internally stable. The clogging in soil- 
geotextile system is then when the values of gradient ratio are GR $>1$.

The main objective of this paper is to present a series of laboratory tested results on internally unstable soils and nonwoven geotextile material. The results are compared with those presented by Haliburton and Wood (1982).

\section{METERIAL AND METHODS}

The characteristics and properties of the nonwoven geotextile material and the soils used in this study are given below.

Geotextiles: Three K-500 geotextile material (Geo1, Geo2 and Geo3) were used in test. The values of apparent opening size and transsmisivity flow obtained from the manufacturer. The physical and hydraulic properties tested geotextiles showed in Table 1.

Soils: Tested soils are identified as slightly clayey sands (Fig. 1). Their physical and hydraulic properties are given in Table 2. The soils G2 and G3 were prepared as a mixed sand and silt medium. Tested soils are internal unstable according to the Kenney and Lau (1985) method the assessment of internal stability soils.

\section{Experimental conditions and measurements}

The tested soils were dried (under $105^{\circ} \mathrm{C}$ for $24 \mathrm{~h}$ ) and sieved with mesh $2 \mathrm{~mm}$. The soil was placed around the geotextile material. In order to avoid and remove the air trapped in the tested soil and geotextile material, the water was delivered into the apparatus from bottom to the top slowly in the beginning for 12 hours. Flow direction was then changed (i.e. from top to bottom). The temperature of the water was $20^{\circ} \mathrm{C}$. When the water flow reached a stable (steady) condition, the following measurements were taken for each of the hydraulic gradients (i) at $1.0,2.5,5.0,7.5$ and 10.0.

- temperature of water flow (T),

- volume of flow (V),

- time of flow (t),

- pressure of individual piezometer $(\Delta \mathrm{h})$.

\section{Experimental setup}

The soil-geotextile testing system was carrying out by using the apparatus shown in Figure 2. It is a modified apparatus from the ASTM D 5101-90 standard by installing additional piezometers $(6$ and

7) in order to obtain additional pressure

TABLE 1. Properties of tested geotextile material, K-500

\begin{tabular}{|l|c|c|c|}
\hline Properties & \multicolumn{3}{|c|}{ Parameters values } \\
\hline Physical & Geo1 & Geo2 & Geo3 \\
Thickness for the applied load $2 \mathrm{kPa}, \mathrm{g}[\mathrm{mm}]$ & 5.15 & 5.19 & 5.31 \\
Mass per unit area, $\mu_{\mathrm{A}}\left[\mathrm{g} / \mathrm{m}^{2}\right]$ & 526.4 & 521.1 & 515.8 \\
Apparent opening size, $\mathrm{O}_{90}[\mathrm{~mm}]$ & 0.06 & 0.06 & 0.06 \\
\hline Hydraulic & & & \\
Hydraulic conductivity (Cross-plane flow), $\mathrm{k}_{\mathrm{v}}[\mathrm{m} / \mathrm{s}]$ & $5.8 \times 10^{-4}$ & $5.6 \times 10^{-4}$ & $5.4 \times 10^{-4}$ \\
Transmissivity (In-plane flow), $\mathrm{k}_{\mathrm{h}}\left[\mathrm{m}^{2} / \mathrm{s}\right]$ & $2.7 \times 10^{-3}$ & $2.7 \times 10^{-3}$ & $2.7 \times 10^{-3}$ \\
\hline
\end{tabular}




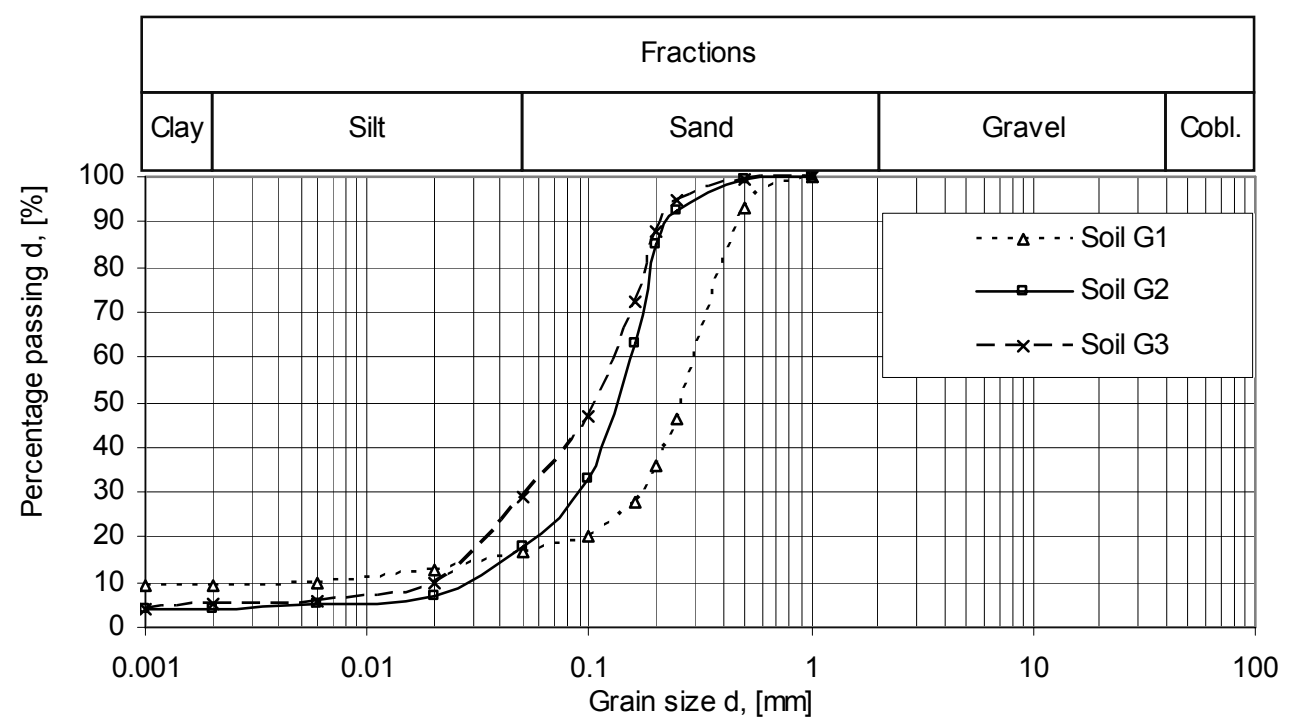

FIGURE 1. Grain size distribution of tested soil

TABLE 2. Physical and hydraulic properties of tested soils

\begin{tabular}{|l|c|c|c|}
\hline Properties & \multicolumn{3}{|c|}{ Parameters values } \\
\hline Physical & $\mathrm{G} 1$ & $\mathrm{G} 2$ & $\mathrm{G} 3$ \\
\hline Slightly Clayey Sand & & & 70 \\
Fractions & 83 & 82 & 25 \\
Sand [\%] & 8 & 14 & 5 \\
Silt [\%] & 9 & 4 & 6 \\
Clay [\%] & 37.5 & 5 & 1.2 \\
Coefficient of uniformity, Cu [-] & 12.4 & 2.1 & 0.21 \\
Coefficient of curvature, Cc [-] & & & 0.12 \\
Size $($ diameter) & 0.47 & 0.21 & 0.02 \\
$\mathrm{~d}_{90}[\mathrm{~mm}]$ & 0.30 & 0.14 & 1.79 \\
$\mathrm{~d}_{60}[\mathrm{~mm}]$ & 0.008 & 0.03 & $6.3 \times 10^{-5}$ \\
$\mathrm{~d}_{10}[\mathrm{~mm}]$ & 1.96 & 1.70 & \\
Density of dry soil, $\rho_{\mathrm{d}}\left[\mathrm{t} / \mathrm{m}^{3}\right]$ & $4.9 \times 10^{-4}$ & $2.8 \times 10^{-4}$ & \\
\hline Hydraulic & & & \\
Permeability coefficient, $\mathrm{k}[\mathrm{m} / \mathrm{s}]$ & & &
\end{tabular}

measurements in layer of soil situated near geotextile material. The following piezometer readings were taken in individual zones.

- for soil-geotextile:

- zone 7-8 (geotextile and $4 \mathrm{~mm}$ layer of soil between piezometers number 7 to 8 ),
- zone 6-8 (geotextile and $8 \mathrm{~mm}$ layer of soil between piezometers 6 to 8$)$,

- zone 4.5-8 (geotextile and $25 \mathrm{~mm}$ layer of soil between piezometers 4 and 5 to 8 ).

- for soil: 
- zone 6-7 (4 mm layer of soil within the distance from 4 to $8 \mathrm{~mm}$ above geotextile between piezometers 6 and 7 ),

- zone 4.5-6 (17 mm layer of soil within the distance from 8 to 25 $\mathrm{mm}$ above geotextile between piezometers 4,5 and 6$)$,

- zone 2.3-4.5 (50 $\mathrm{mm}$ layer of soil within the distance from 25 to $75 \mathrm{~mm}$ above geotextile between piezometers 2 and 3 as well as 4 and 5.

The following equation (1) is used to calculate the gradient ratio in soilgeotextile system: GR (ASTM D-5101) $=\mathrm{GR}_{25}$ (see Fig. 4 for definition sketch).

$$
\begin{aligned}
G R_{25} & =\frac{\left(\frac{h_{4}+h_{5}}{2}-h_{8}\right) / L_{4}}{\left(\frac{h_{2}+h_{3}}{2}-\frac{h_{4}+h_{5}}{2}\right) / L_{2-4}}= \\
& =\frac{\Delta h_{4.5-8} / L_{4}}{\Delta h_{2.3-4.5} / L_{2-4}}
\end{aligned}
$$

where:

$\Delta \mathrm{h}_{4.5-8}=$ is the difference manometer readings between average reading of 4 and 5 piezometers and 8 piezometer $[\mathrm{mm}]$,

$\Delta \mathrm{h}_{2.3-4.5}=$ is the distance in manometer readings between average reading of 2 and 3 piezometers and average reading of 4 and 5 piezometers [mm].

The relationship for the evaluation of the change gradient ratio (for the soil

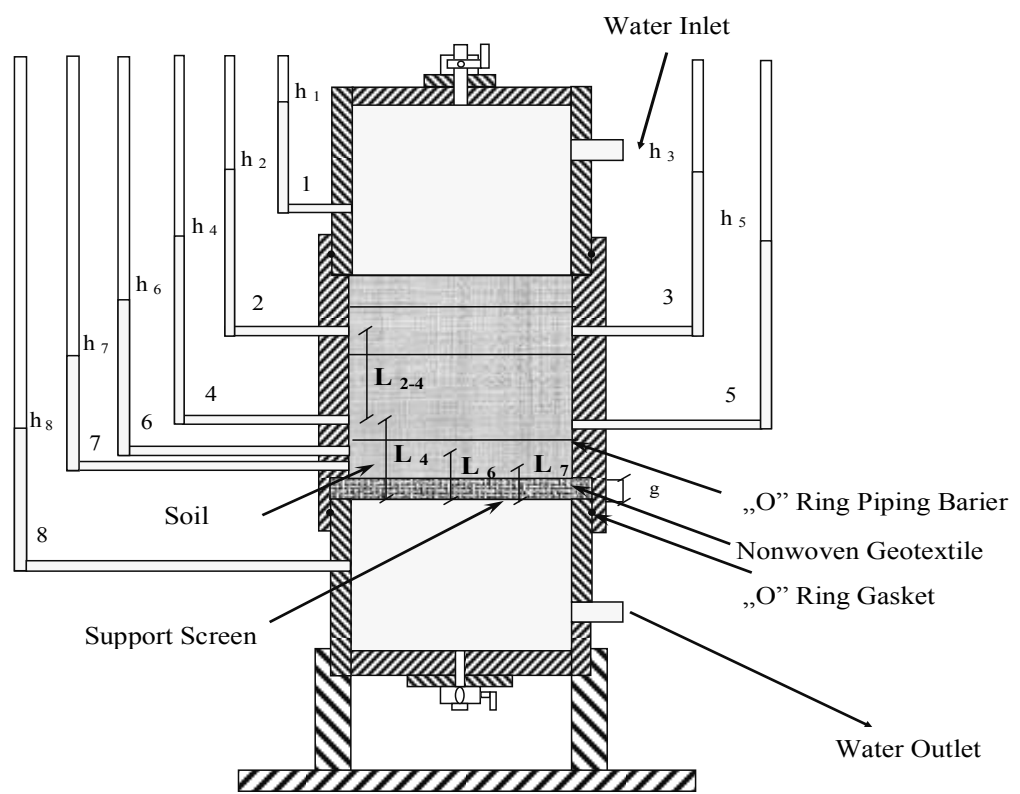

FIGURE 2. Experimental setup

$\mathrm{h}_{\mathrm{n}}$ is the manometer reading for $\mathrm{nth}$ manometer [mm],

$\mathrm{L}_{\mathrm{n}}=$ is the distance between piezometer $\mathrm{nth}$ and the bottom of geotextiles [mm],

$\mathrm{L}_{2-4}=$ is the distance between piezometers 2 to $4[\mathrm{~mm}]$,

$\mathrm{g}$ - thickness of geotextile [mm]. 
layers 17 and $4 \mathrm{~mm}$ above the geotextile) RESULTS is proposed:

$$
\begin{aligned}
S G R_{17} & =\frac{\left(\frac{h_{4}+h_{5}}{2}-h_{6}\right) / L_{4-6}}{\left(\frac{h_{2}+h_{3}}{2}-\frac{h_{4}+h_{5}}{2}\right) / L_{2-4}}= \\
& =\frac{\Delta h_{4.5-6} / L_{4-6}}{\Delta h_{2.3-4.5} / L_{2-4}} \\
S G R_{4} & =\frac{\left(h_{6}-h_{7}\right) / L_{6-7}}{\left(\frac{h_{2}+h_{3}}{2}-\frac{h_{4}+h_{5}}{2}\right) / L_{2-4}}= \\
= & \frac{\Delta h_{6-7} / L_{6-7}}{\Delta h_{2.3-4.5} / L_{2-4}}
\end{aligned}
$$

The permeability coefficient of geotextile material measured was slightly higher (influence of structure material) than the value provided by the manufacturer. During the filtration process, the maximum difference of the permeability coefficients was obtained in the most internal unstable soil G1. Permeability coefficient decreased about 15 times

(2) from $\mathrm{k}_{\text {geo }}=5.8 \times 10^{-3}$ to $4.0 \times 10^{-4} \mathrm{~m} /$ s. In soils $\mathrm{G} 2$ and G3, it decreased by 4 and 6 times, respectively. The change of gradient ratio for individual hydraulic gradient is shown in the Figures 3, 4 and 5 .

Tested results showed that gradient ratio value in soil-geotextile system

where:

(3) $\left(\mathrm{GR}_{25}\right)$ decreased in comparison with $\Delta \mathrm{h}_{4.5-6}=$ is the difference manometer readings between average reading of 4 and 5 piezometers and 6 piezometer [mm],

$\mathrm{L}_{4-6}$ is the distance between piezometers 4 to $6[\mathrm{~mm}]$,

$\mathrm{L}_{6-7}$ is the distance between piezometers 6 to $7[\mathrm{~mm}]$. gradient ratio in soil $\left(\mathrm{SGR}_{17}\right.$ and $\left.\mathrm{SGR}_{4}\right)$. The largest difference was found in the soil layer immediately above the geotextile material. Tested results also showed that significant clogging occurred in the $17-\mathrm{mm}$ soil layer situated in distance from 8 to $25 \mathrm{~mm}$ above geotextile material. Figure 6 gives the comparisons of the tested results

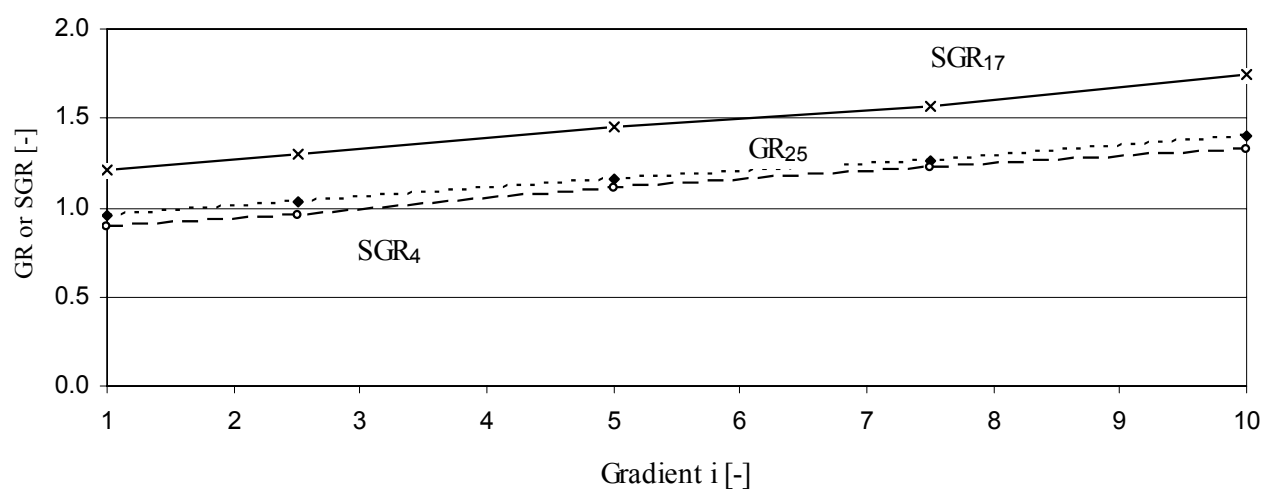

FIGURE 3. The change of gradient ratio and soil-gradient ratio under hydraulic gradient from 1 to 10 in soil G1 (fines - 17\%) 


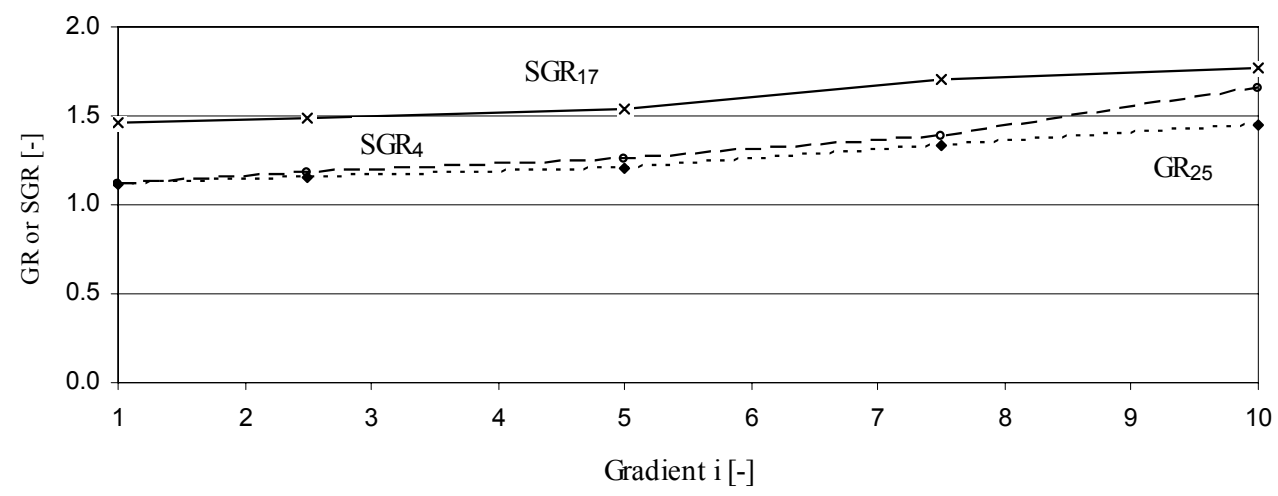

FIGURE 4. The change of gradient ratio and soil-gradient ratio under hydraulic gradient from 1 to 10 in soil G2 (fines - 18\%)

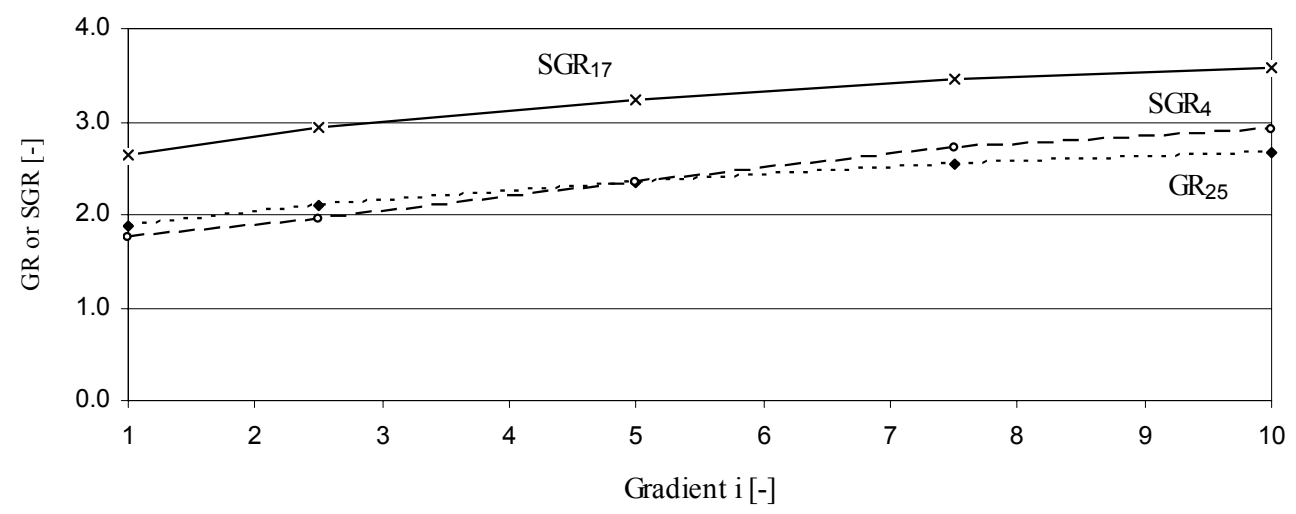

FIGURE 5. The change of gradient ratio and soil-gradient ratio under hydraulic gradient from 1 to 10 in soil G3 (fines - 30\%)

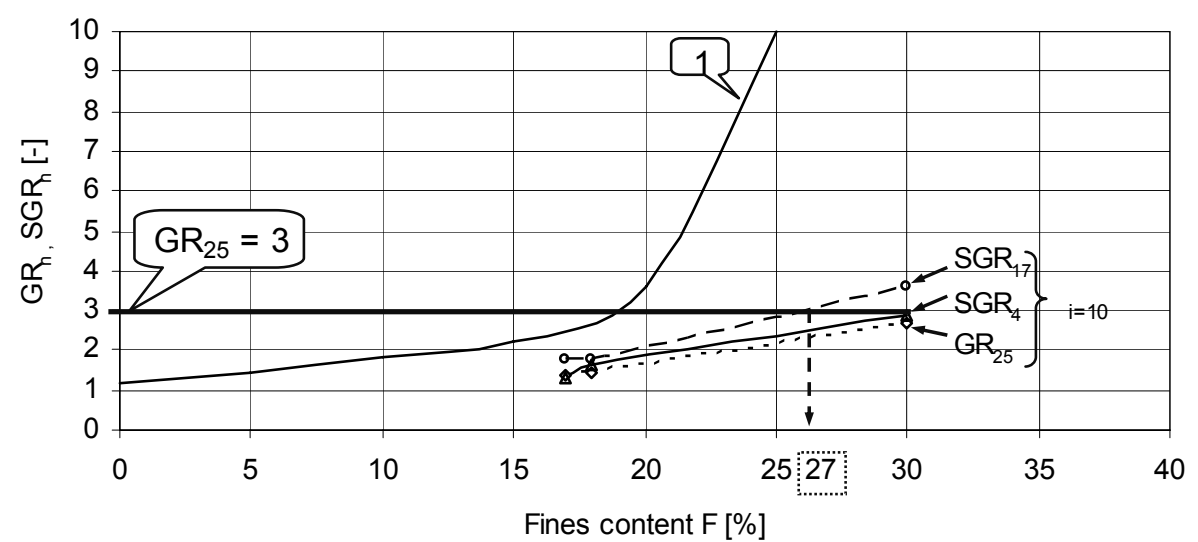

FIGURE 6. The change of gradient ratio depending on fines content in soils Curve 1: reported by Haliburton and Wood (1982) 
obtained in this study with quantify the clogging potential geotextiles in contact with soil-silt content by Halliburton and Wood (1982). Fabric should definitely not be used in critical design applications where soil-geotextile system gradient ratio $\left(\mathrm{GR}_{25}\right)$ exceeds 3.0

From Figure 6, it can be seen that when the criteria proposed by Haliburton and Wood (1982) is used, the $\mathrm{GR}_{25}$ value (within the range of external hydraulic gradient $i=1$ to 10 ) in the tested soils did not exceed the limit of $\mathrm{GR}_{25}=3$. However, soil gradient ratio $\mathrm{SGR}_{17}$ for soil G3 (with $30 \%$ of fines) exceeds this limit when the hydraulic gradient (i) was larger than 2.5 (Figure 5). The results show that the all three geotextile material can be used as the filtration layer for any soil with fines $(\mathrm{d}<0.05 \mathrm{~mm}) 27 \%$ content.

\section{CONCLUSIONS}

1. Permeability coefficient under different hydraulic gradient during long time test (about $2100 \mathrm{~h}$ ) was changed decrease from initial value to finished about 4 to 15 times.

2. During filtration process-clogging phenomena was very intensive in 17 $\mathrm{mm}$ layer situated in distance from 8 to $25 \mathrm{~mm}$ above geotextile material.

3. Nonwoven geotextile K-500 based on formula soil gradient ratio $\left(\mathrm{SGR}_{17}\right)$ according to the Haliburton and Wood criterion (1982) can cooperate with internal unstable soil with fine content $(\mathrm{d}<0.05 \mathrm{~mm})$ of $27 \%$.

\section{REFERENCES}

ASTM D-5101 (1990): Standard Test Method for Measuring the Soil-Geotextile System Clogging Potential by the Gradient Ratio.

CALHOUN C.C. 1972: Development of design criteria and acceptance specifications for plastic filter cloth. USAGE. Waterways Experimental Station, Vicksburg.

FISHER G.R., MARÉ A.D, HOLTZ R.D. 1999: Influence of Procedural Variables on the Gradient ratio Test. Geotechnical Testing Journal, Vol. 22, No 1, 22-31.

GIROUD J.P. 1982: Filter criteria for geotextiles. 2nd Int. Conf. On Geotextiles, Geomembranes and Related Products, Las Vegas, 103-108.

HALIBURTON T.A., WOOD P.D. 1982: Evaluation of the U.S. Army Corps of Engineers Gradient Ratio Test for Geotextile Performance. 2nd Int. Conf. On Geotextiles. Las Vegas, Nevada, 97-101.

HEERTEN G. 1983: Filtereigenschaften von Geotextillien für den Erd - und Wasserbau. Wasser und Boden, 348-353.

HUANG HSU-YEH., GAO XIAO: 2008: Geotextiles (www.engr.utk.edu/mse/ Textiles/Geotextiles.htm)

KENNEY T.C., LAU D. 1985: Internal stability of granular filters. Canadian Geotechnical Journal, Vol. 22, No 2, 215-225.

LAWSON C.R. 1987: Use of Geotextile for Subsurface Drainage in South East Asian Context. International Symposium on Geosynthetics, Kyoto, Japan, 145-165. 
ROLLIN A.L. 1986: Filtration opening size of Geotextiles. ASTM Standardization News, 50-52.

Streszczenie: Ocena nietkanej geowtókniny jako warstwy filtracyjnej $w$ kontakcie z gruntami wewnętrznie niestabilnymi. $\mathrm{W}$ artykule przedstawiono wyniki laboratoryjnych badań trzech nietkanych geowłóknin, wykorzystanych jako warstwa filtracyjna ochraniająca trzy wewnętrznie niestabilne pisaki gliniaste. Badania przeprowadzono w aparacie według normy ASTM D-5101 (1990), który poddano modyfikacji poprzez zainstalowanie dodatkowych piezometrów w odległości 4 i $8 \mathrm{~mm}$ powyżej badanego materiału syntetycznego. Zastosowane piezometry podczas badań umożliwiły odczyt ciśnienia w warstwie gruntu znajdującej się w bliskiej odległości od geowłók- niny. Badania laboratoryjne przeprowadzono przy zewnętrznych gradientach hydraulicznych w zakresie $i=1 \div 10$. Na podstawie uzyskanych badań została zaproponowana zależność oceniająca zmiany stosunku gradientów w gruncie (17 $\mathrm{mm}$ warstwa gruntu znajdująca się w odległości 8-25 mm gruntu powyżej geowłókniny) w układzie grunt-geowłóknina na podstawie zewnętrznego gradientu hydraulicznego oraz zawartość frakcji drobnych $\mathrm{w}$ gruncie.

MS. received November 2008

\author{
Author's address: \\ Dariusz Wojtasik \\ Katedra Geoinżynierii SGGW \\ 02-776 Warszawa, ul. Nowoursynowska 159 \\ Poland \\ e-mail: dariusz_wojtasik@sggw.pl
}

